\title{
Work Choices: the low productivity road to an underclass
}

Sally Cowling, Robert LaJeunesse, William Mitchell, and Martin Watts

\begin{abstract}
The passage of the Work Choices Act 2005 serves to eliminate one of the last symbols of fairness in Australian society; the judicially-determined conciliation and arbitration system and wage-setting machinery. In this paper we examine the flawed conceptual framework, which underpins the Government's view that reducing the rights and protections of workers will produce superior labour market outcomes. We argue that the principal failure of the Work Choices Act is that it ignores the role of macroeconomic policy in directly addressing the efficiency and equity issues that have been said to motivate its provisions. The Act also ignores the different bargaining power of workers and capital and pays no attention to the serious social repercussions that will flow when labour is treated like a commodity. The imperative to minimise labour costs under Work Choices will spur a race to the bottom and the profusion of insecure, low-paid, poor-quality work in an economy characterised by allocative and dynamic inefficiency.

Keywords: Work Choices, minimum wages, labour market deregulation
\end{abstract}




\section{Introduction}

The Workplace Relations Amendment (Work Choices) Act 2005 was proclaimed on March 27, 2006. The Australian Government (2005) posits that the reforms will generate a fairer balance of forces within the labour market and lead to higher employment, productivity and real wages. These changes are deemed essential given Australia's increasing exposure in a globalised economy.

The origins of Work Choices can be traced to the neo-liberal economic reform agenda that emerged in response to the inflation breakout following the first oil price shock in the mid-1970s. This agenda gained additional impetus with the publication of the Jobs Study by the Organisation of Economic Cooperation and Development (OECD) in 1994. This blueprint for reform was grounded in the primacy of markets, and the imperative to remove the institutional ferters which allegedly inhibited their operation. Active macroeconomic policy was eschewed and the pursuit of tight monetary policy and budget surpluses, to constrain inflation, was advocated.

In embracing these prescriptions, the Australian Government has ignored the macroeconomic consequences of having nearly 1.8 million workers without sufficient work (Keating, 2005) and has established pernicious compliance regimes to ensure that unemployed and marginalised workers are blamed and punished for their circumstances.

With the introduction of Work Choices, one of the last symbols of fairness in our society - the judicially-determined conciliation and arbitration system and wage-setting machinery - has been eliminated. The economic and social consequences already being experienced are likely to be more profound than those flowing from previous changes in the conduct of industrial relations. While low-paid workers will bear the brunt of the impact, few workers will be garrisoned from the radical and damaging transformation in the way we work, earn income, take leisure, and engage in social relationships.

\section{A conceptual framework}

\subsection{Methodological Individualism}

The theoretical perspective underpinning the Work Choices Act argues that reducing the rights and protections for workers will promote individual bargaining with employers, providing both parties with a broader range of choices about workplace arrangements and producing superior labour market outcomes. Two caveats are important here. First, despite the mantra of flexibility, the legislation is highly prescriptive, particularly with respect to allowable matters in agreements. Second, the current macroeconomic policy framework, which remains entrenched as the backdrop to the legislation, has resulted in the stagnation of median real minimum wages over two decades.

The neo-liberal policy approach draws on the textbook model of perfect competition for its theoretical imprimatur. This orthodox model argues that the establishment of market-clearing equilibrium is guaranteed by the presence of wage and price flexibility. Ipso facto the failure of markets to clear is a result of prices and/or wages being inflexible, which would reflect market imperfections, including labour market regulations, impinging on the exercise of free choice by economic agents. 
This model is devoid of the institutional, social and political context in which asymmetries of power and information, bounded rationality, tradition, myopia and a myriad of other influences bring about so-called imperfections in the functioning of markets. In particular, no power is assumed to be exercised by the large number of autonomous agents who interact in impersonal product and labour markets, with the labour exchange indistinguishable from the exchange for lemons or any other commodity (Polanyi, 1957). Accordingly, the object is exchanged for money and use values are transferred between worker and employer to be consumed outside the exchange. This construction fails to recognise that labour is a special commodity because the employer consumes the use values of the exchange during the work process rather than after the exchange, and because the worker relies on employment for both sustenance and social identity (Cowling and Mitchell, 2005: 201).

This power imbalance in the employment relationship was codified in the Australian industrial relations system in the 1907 Harvester decision which recognised that the anarchy of the market would rarely generate a fair distribution of wages, due to the imbalance of bargaining power. The Basic Wage was defined as a social minimum living wage. Market constructs such as the capacity to pay were subjugated by this social wage concept. A fair society, which, by definition, would exclude the creation and perpetuation of an under-class, required that the distributional system be legally regulated. For this reason industrial relations were given a specialised judicial process. The development of labour-specific, union-oriented arbitration and conciliation processes in Australia reflected a need for labour law to redress the power imbalance, which placed workers in a subordinate position to employers (Mitchell, 2005: 2).

The clear intent of the Work Choices Act is for wages and conditions to be determined by market forces. Equity and social justice issues are ignored through reducing the perceived importance of minimum wage adjustment. This begs the question of whether the negotiation of individual contracts - via the imposition of Australian Workplace Agreements (AWAs) on possibly unwilling employees - is appropriate within an equitable industrial relations system. Until recently Australian legal practice has not regarded labour market relations as being best regulated by commercial law. Labour or employment law was seen as being distinct with certain rights and responsibilities that transcended commodity exchange. Common law, in particular, leaves unorganised labour vulnerable. Certainly successive rounds of reform since the acceptance of enterprise bargaining by the Australian Industrial Relations Commission (AIRC) in 1991 and the enactment of the Workplace Relations Act 1996, encompassing the promotion of AWAs, have not created a de facto competitive labour market.

\subsection{Macroeconomics}

The Work Choices legislation lies within the broad policy framework of the 'new macroeconomic consensus' and the OECD Jobs Study agenda (OECD 1994). Orthodox economists extend microeconomic market clearing principles to the operation of the macroeconomy. Keynes (1936) and later the Post Keynesians demonstrated that the presence of perfect competition was neither necessary nor sufficient for the achievement of full employment (Davidson 1994). The conceptual leap from microeconomic market clearing propositions to full employment involves a fallacy of composition that is omnipresent in the public policy debate and the economics literature. 
The experience of World War II showed governments that full employment could be maintained with the appropriate use of budget deficits. At the War's end, governments had to translate the full employed war economy with extensive civil controls and loss of liberty into a fully employed peacetime model. The emphasis of macroeconomic policy was on achieving full employment by generating enough jobs. The control of inflation was a secondary concern.

The rise in inflation in the mid-1970s deteriorated into stagflation when governments failed to develop appropriate macroeconomic responses to the oil price impulse. The emergence of stagflation revealed ideological fissures among Keynesians. These were previously masked by the prosperous post-war consensus between government, labour and business. The rift led to the development of 'New-Keynesianism' - a paradigm obsessed with economic rigidities, such as trade unions and minimum wages - which served as a precursor to the neo-liberal agenda centred on labour market flexibility (Palley, 2004). This professional discord assisted the articulation of a consensus based on methodological individualism in leading Western nations. The reform paradigm became prominent in the policy recommendations of international economic organisations, including the OECD's Jobs Study.

Monetary policy in the wake of the oil crises was geared to control inflation while fiscal policy was designed to passively support this aim through the pursuit of balanced budgets over the business cycle. The Australian Government has redefined fiscal policy in terms of the imperative to achieve persistent surpluses and to sustain the economy at the rate of unemployment at which the inflation rate is alleged to be stable. This macroeconomic paradigm was buttressed by specific microeconomic reform proposals. These focused on the labour market to rid the OECD economies of what was deemed to be a sclerosis, reflecting years of regulation and income transfer policies that had eroded individual incentive and institutionalised high unemployment rates.

Before outlining and investigating some of the weaknesses of the Work Choices Act, we note some stylised facts that challenge the alleged macroeconomic success of the present neo-liberal agenda. In February 2006, the official unemployment rate was 5.2 per cent, which is well above the rate experienced in the immediate post-war period. Moreover, a broader hours-based measures of labour underutilisation (incorporating hidden unemployment and underemployment) calculated by the Centre of Full Employment and Equity (CofFEE) indicated that 9.9 per cent of willing labour resources were unused. The quality of the work undertaken has also deteriorated with the growth of jobs characterised by precarious tenure, low pay and non-standard working hours (Borland $e t$ al., 2001).

The persistent labour wastage indicates that net government spending is too low (Mitchell and Mosler, 2002) and the preoccupation with budget surpluses has introduced significant fiscal drag into the growth cycle. The willingness of households to become increasingly indebted has driven economic growth for some time. This growth strategy is unsustainable and will eventually lead to an entrenched recession as households resume saving and reduce their debt exposure.

Freeman (2005: 1) notes that the debate about the determinants of economic performance has shifted from the conduct of macroeconomic policy to the degree 
of labour market deregulation. Empirical studies will be flawed, unless they recognise that outcomes (particularly employment and productivity) will be influenced by macroeconomic policy settings. Firms hire workers to produce goods and services that they can sell. Thus, at prevailing wage levels, aggregate employment is a function of the demand for the output that workers produce. The Work Choices legislation can only bring about putative employment gains if the envisaged reductions in wage growth and erosion of working conditions serve to increase household consumption; stimulating aggregate demand and, with a lag, labour demand. Clearly, this is most unlikely. Wage erosion is likely to reduce aggregate demand, and further diminish demand for labour.

Persistent unemployment has no basis in a lack of labour market flexibility. Instead, the macroeconomic policy (on-going budget surpluses) pursued by the Australian Government remains the major cause of labour market slack. There is also a failure to understand that government expenditure is not subject to the financing constraints that apply to households. Deficits, which are calibrated to provide enough fiat currency to 'finance' the private sector's desire to net save in the currency of unit, are necessary to achieve full employment unless alternative employment policies are introduced. CofFEE advocates a Job Guarantee, which provides a minimum wage job in the public sector to all workers who want one. It is one way to regulate the minimum extra spending that is required by the Federal Government to ensure that everyone who wants to work can get a job (Mitchell and Wray, 2005). We now examine the provisions and likely impact of the Work Choices legislation based on this conceptual framework.

\section{The Impact of the Work Choices Legislation}

\subsection{Wage Setting}

The new legislation guarantees that nominal minimum and award classification wages will be protected at the current weekly Federal Minimum Wage (FMW) of \$484.40. The Australian Fair Pay Commission (AFPC) will be required to place greater emphasis on promoting economic prosperity, through employment generation, in determining the subsequent adjustment of the FMW. Given that the establishment of the AFPC has been explicitly linked to the view that the generosity of AIRC Safety Net decisions has been to the detriment of employment growth, it is reasonable to expect that the real minimum wage will fall over time or grow at a considerably slower rate. Briggs and Buchanan (2005) note that the reforms will also impact on a cohort of skilled workers who lack bargaining power and on low paid workers who earn above the FMW but for whom safety net increases represent a floor underpinning their wages.

The AFPC will determine the timing, scope and frequency of its wage reviews, the manner in which wage reviews are to be conducted and the date on which wage-setting decisions are to come into effect (House of Representatives, 2005: 20). Cowling and Mitchell (2005) argue that the independence of the AFPC is compromised by the relatively short tenure of its members prior to re-appointment and the capacity of the Commonwealth to recruit sympathetic members within the selection criteria. While the Department of Employment and Workplace Relations (DEWR) states that the AFPC wage reviews are designed to be inclusive and that the Commission can undertake or commission research, engage in consultation, and monitor and evaluate the impact of 
its wage-setting decisions, this will be for the AFPC to determine alone. The AFPC can choose to publish its wage-setting decisions, without supporting evidence.

By contrast, at Safety Net reviews, previously conducted by the Full Bench of the AIRC, a range of parties and expert witnesses presented evidence, were questioned by the Commissioners, and were subject to cross-examination. The AIRC not only published its decisions, but also a detailed evaluation and assessment of the evidence presented to explain the basis on which its determination was made (Cowling and Mitchell, 2005).

Also in contrast to the AIRC, the AFPC will not be required to consider 'fairness' and living standards as part of the four legislated wage-setting parameters. These parameters (House of Representatives, 2005: 49) are:

a. The capacity of the unemployed and the low paid to remain in employment.

b. Employment and competitiveness across the economy.

c. Providing a safety net for the low paid.

d. Providing minimum wages for junior employees, employees to whom training arrangements apply and employees with disabilities that ensure those employees are competitive in the labour market.

The exclusive focus on labour costs is likely to promote overly cautious wage decisions, particularly when economic activity slows. Importantly, the Work Choices Act fails to recognise that "fairness among workers and fairness among the population are not the same thing" (Richardson and Harding, 1999: 152). While increasing the minimum wage will not, in isolation, have a potent and equalising impact on the distribution of household income, the Commission should be charged with ensuring 'fair pay' so that a minimum wage rate is determined that prevents worker exploitation and provides a level of remuneration which represents the worker's contribution to the value of output.

In addition, parameter (c) will require the AFPC to respond to Government decisions, which influence the household distribution of income - such as changes to rates and thresholds within the personal income tax system and the level, and targeting, of income support payments - as opposed to making determinations about appropriate wage settings per se. This decision-making process leaves no room for consideration of what constitutes a fair division of production between labour and capital. This represents an important shift from the determination of a fair social minimum, and the recognition that labour is a special commodity, which underpinned the 1907 Harvester Judgment.

\subsection{Employment effects}

Without providing specific estimates, DEWR argued at the 2005-06 Budget Senate Estimates Hearings that the operation of the AFPC would benefit employment creation:

DEWR has provided considerable evidence of the negative effects on employment arising from the operation of the current Workplace Relations Act 1996 where the Australian Industrial Relations Commission (AIRC) continues to grant large wage rises in the annual Safety Net Review... The AFPC will ensure a better balance between fair pay and employment.

DEWR (2005: W319-06) 
Economists and employer groups have long claimed in their submissions to wage setting tribunals that wage increases, or the imposition of minimum wages and conditions, will have adverse consequences for employment (see, for example, AIRC: 2003, 2004, 2005). This proposition is grounded in the orthodox microeconomic theory outlined in Section 2 , however empirical support is tenuous. Significant interdependencies between labour demand and supply are typically ignored by those who use 'text-book' theory as an 'authority' for their claims (Thurow, 1983).

Despite abundant international evidence (Card and Krueger, 1994; Machin and Manning, 1994; Borland and Woodbridge, 1999; and Watson, 2004), the debate about the impact of a minimum wage increase remains unresolved and largely divides along ideological lines. Neoclassical economists have used a litany of poorly constructed empirical research to draw a negative association between real wage rises and employment. The OECD (1998) is now more equivocal about the role of minimum wages on employment and acknowledges that a rise in the minimum wage has not unambiguously led to job losses for youth. It still argues that (unspecified) high levels of minimum wages will be detrimental to employment.

In its May 2004 Safety Net decision the AIRC (2004: Paragraph 229) states:

After yet another survey of the literature and other material on the economic effects of increases in minimum wages it has clearly emerged, once again, that most of the information is of very limited assistance. The research is either largely irrelevant, is limited in scope, or has serious methodological flaws.

With the scrapping of the no disadvantage test, the 'race to the bottom', within the limits defined by the Australian Fair Pay and Conditions Standards, has begun. Recent reports of marginal retailers and meatpackers firing workers and offering to re-hire them on AWAs, serve as a harbinger of downward wage movements that even progressive employers will be pressured to pass along to their workers. Disadvantaged workers who lack bargaining power will be forced to accept AWAs and other individual agreements with terms and conditions below the relevant award standard or face dismissal. The unemployed will still be required to take any work that is offered to them, irrespective of the contractual arrangements, or have their unemployment benefits suspended. Thus employers have significantly more power under WorkChoices and take-it-or-leave-it contracts are likely to become widespread.

It is important to recall that the periodic increase of minimum wage levels can force low wage firms to raise labour productivity through new investment, rather than compete on the basis of wage cuts. If properly implemented, statutory minimum wages can reduce earnings inequality, ensure a fairer distribution of economy-wide productivity gains and build prosperity from the bottom up by increasing incentives to work at a living wage, particularly for welfare dependent youth. This is an important alternative to current policy settings that has gone largely ignored in countries such as Britain, the USA, Australia and New Zealand where a policy of trickle-down economics has been pursued (Palley, 1998). 


\subsection{Workplace reform and economic performance}

Under Work Choices, corporate employers with fewer than 100 employees are exempt from unfair dismissal laws and will be able to summarily dismiss their workers with relative impunity. For larger firms, widely defined operational reasons will be sufficient to justify workforce reductions. The incentive for capricious behaviour will be compelling. Few workers will seek legal redress for unlawful dismissal, because of the expense, legal complexity and time lags of common law claims, coupled with the fact that successful actions do not offer reinstatement. While a tight labour market may discipline rogue employer behaviour, the real hardships for many workers will arise during the next business cycle contraction.

Calling on the authority of the textbook competitive model, the Government justifies the elimination of unfair dismissal protection on the grounds that regulatory constraints impact negatively on economic performance, particularly employment growth. Following the Jobs Study, researchers have attempted to assess the impact of institutional arrangements on economic performance. Authoritative labour economists, including Baker et al., (2004) and Freeman (2005) have not found that free market reforms have led to a statistically significant fall in unemployment. The OECD $(1998,1999)$ and the World Bank (2003) are now more equivocal about the professed impact of proposed reforms. Nor does Australian empirical work support the Commonwealth's implicit proposition that, by providing access to career opportunities, any job is better than no job (for example, Burgess and Campbell, 1998; Dunlop, 2000).

Institutional arrangements which enable wage cutting in a macroeconomic environment of underutilised labour will not promote on-the-job training and increased productivity, despite exaggerated claims about skill shortages in Australia. Mitchell and Quirk (2005) argue that the persistently high levels of labour underutilisation and emerging skills shortages in some specialised areas both reflect a lack of governance, exemplified by the reduction in public sector employment and training structures. Work Choices entrenches the view that the private market can deliver dynamic training responses to occupational demands, despite significant evidence to the contrary. The international research literature finds that the industrial relations regime of a country can impact adversely on the human resource strategy of an innovating firm (see LaJeunesse, Mitchell and Watts 2006).

Finally there are many parallels between the objectives of Work Choices and the disastrous industrial relations experiment conducted in New Zealand during the 1990s. The outcomes of the Employment Contracts Act offer relevant evidence of the relationship between unions and labour productivity. Although the 1991 legislation was successful in accelerating the decline of unions - with union density falling by 50 per cent in less than a decade - labour productivity growth collapsed between 1993 to 1998 , reflecting the deterioration of morale, trust, loyalty, and good faith in the workplace (May et al., 2002). 


\section{Conclusion - a better way forward}

In February 2006, despite fourteen years of sustained economic growth, 9.9 per cent of willing labour hours were being wasted in Australia (CofFEE, 2006). The Work Choices legislation represents the continuation of a neo-liberal reform agenda based on the discredired premise that shifting the balance of power within the labour market will lead to full employment. As such, the legislation represents a significant 're-regulation' rather than a deregulation of the labour market.

Under Work Choices, the imperative to minimise labour costs will spur a race to the bottom and the profusion of insecure, low-paid, poor-quality work. Not only will this strategy fail to achieve full employment, but the economy will be characterised by allocative inefficiency. A low-wage regime represents a subsidy to inefficient firms by enabling them to remain viable. In addition, the failure of the Act to promote physical and human capital formation to raise productivity signals dynamic inefficiency and a future characterised by stagnant real wages and living standards, and declining international competitiveness (Buchanan and Callus 1993).

Demographic trends may well lead to a long-term tightening of the labour market, and increased bargaining power for more highly skilled workers. However, low-skilled workers, with limited bargaining power, will always be vulnerable to reductions in wages and conditions irrespective of the state of the business cycle. In the modern labour market the low-wage worker serves as a macroeconomic buffer for both inflation and wider unemployment among the lower- and middle-classes.

The Work Choices Act is of value only because it recognises the serious social problem of labour underutilisation. The travesty of the legislation is that it ignores the role of macroeconomic policy in directly addressing the efficiency, fairness and distributional issues that have been said to motivate its provisions. The Bill also ignores the different bargaining power of workers and capital and pays no attention to the serious social repercussions that will flow when labour is treated like a commodity.

To directly address the cause of unemployment and ameliorate income inequality requires the State to use its fiscal powers to achieve and maintain full employment. Mitchell, (1998) outlined the Job Guarantee approach in which the public sector would maintain a 'buffer stock' of minimum wage jobs available to anyone willing and able to work as the most expedient means of addressing unemployment. This approach does not rely on engineering labour supply adjustments by paring back real wages at the bottom of the earnings distribution. 


\section{References}

Australian Government (2005) Work Choices: A New Workplace Relations System, Commonwealth of Australia, October.

Australian Industrial Relations Commission (AIRC) (various years) 'Safety Net Review Wages', Decision and Statement. Available at: http://www.e-airc.gov.au/

Baker, D., Glyn, A., Howell, D.R. and Schmitt, J. (2004) 'Labor Market Institutions and Unemployment: A Critical Assessment of the Cross-Country Evidence', in Howell, D.R. (ed.) Fighting Unemployment: The Limits of Free Market Orthodoxy, Oxford University Press, Oxford.

Borland, J., Gregory, R.G. and Sheehan, P. (2001) Work Rich, Work Poor: Inequality and Economic Change in Australia, Centre for Strategic Economic Studies, Melbourne.

Borland, J. and Woodbridge, G. (1999) 'Wage Regulation, Low Wage Workers and Employment', in Richardson, S. (ed.) Reshaping the Labour Market: Regulation, Efficiency and Equality in Australia, Cambridge University Press: Melbourne.

Briggs, C. and Buchanan, J. (2005) 'Work, Commerce and Law: A New Australian Model?', Australian Economic Review, 38(2), 182-191, June.

Buchanan, J. and Callus R. (1993) 'Efficiency and Equity at Work: The Need for Labour Market Regulation', Journal of Industrial Relations, 35(4), 515-527.

Burgess, J. and Campbell, I. (1998) 'The Nature and Dimensions of Precarious Employment in Australia', Labour and Industry, 8(3), 5-22.

Card, D. and Krueger, A.B. (1994) 'Minimum Wages and Employment: A Case Study of the Fast-Food Industry in New Jersey and Pennsylvania', The American Economic Review, 84(4), 772.793.

CofFEE (2006) CofFEE Labour Market Indicators, Centre of Full Employment and Equity, February. Available at http://e1.newcastle.edu.au/coffee/

Cowling, S. and Mitchell, W.F. (2005) 'Taking the Low Road: Minimum Wage Determination Under WorkChoices', in Wrightson, G. (ed), Creating a Culture of Full Employment, Proceedings of the $7^{\text {th }}$ Path to Full Employment Conference and the $12^{\text {th }}$ National Conference on Unemployment, December, 196-206.

Davidson, P. (1994) Post Keynesian Macroeconomic Theory, Edward Elgar, Aldershot.

Department of Employment and Workplace Relations (DEWR) (2005) Answer to Question on Notice W319-06, 2005-06 Budget Senate Estimates Hearing, May.

Dunlop, Y. (2000) 'Labour Market Outcomes of Low Paid Adult Workers', ABS Cat. No. 6293.0.00.005, Australian Bureau of Statistics, Canberra.

Freeman, R.B. (2005) 'Labour Market Institutions without Blinders: The Debate over Flexibility and Labour Market Performance', Working Paper 11286, National Bureau of Economic Research, Cambridge, MA.

House of Representatives (2005) 'Workplace Relations Amendment (WorkChoices) Bill 2005', Explanatory Memorandum, The Parliament of the Commonwealth of Australia, November. 
Keating, M. (2005) 'Increasing Employment Participation in Australia and How to Finance It', Paper presented to Transitions and Risk: New Directions in Social Policy Conference, University of Melbourne, February.

Keynes, J.M. (1936) The General Theory of Employment, Interest and Money, Macmillan, London.

LaJeunesse, R., Mitchell, W.F. and Watts, M.J. (2006) 'Economics and Industrial Relations: Debunking the Myths', in Teicher, J., Lambert, R. and O'Rourke, A. (eds.) WorkChoices: The New Industrial Relations Agenda, Pearson Education, Australia, 123-141.

Machin, S. and Manning, A. (1994) 'The Effects of Minimum Wages on Wages Dispersion and Employment: Evidence from the UK Wages Councils', Industrial and Labor Relations Review, 47, 319-329.

May, R., Walsh, P., Harbridge, R. and Thickett, G. (2002) Unions and Union Membership in New Zealand: Annual Review, Industrial Relations Centre, Victoria University, Wellington.

Mitchell, W.F. (1998) 'The Buffer Stock Employment Model - Full Employment without a NAIRU', Journal of Economic Issues, 32(2), 547-55.

Mirchell, W.F. (2005) 'Industrial Relations Changes: The Final Demise of a 'Fair Go' Society!', New Matilda, May.

Mitchell, W.F. and Mosler, W.B. (2002) 'Fiscal policy and the Job Guarantee', Australian Journal of Labour Economics, 5(2), 243-60.

Mitchell W.F. and Wray, L.R. (2005) 'In Defence of the Employer of Last Resort' Journal of Economic Issues, March, 39(1), 235-45.

Mirchell W.F. and Quirk, V. (2005) 'Skill Shortages in Australia: Concepts and Reality', in Wrightson, G. (ed.) Creating a Culture of Full Employment, Proceedings of the $7^{\text {th }}$ Path to Full Employment Conference and the $12^{\text {th }}$ National Conference on Unemployment, December, 307-323.

OECD (1994) OECD Jobs Study, Evidence and Explanations, Organisation of Economic Cooperation and Development, Paris.

OECD (1998) 'Making the Most of the Minimum: Statutory Minimum Wages, Employment and Poverty', OECD Employment Outlook, Organisation of Economic Cooperation and Development, Paris.

OECD (1999), 'Employment Protection and Labor Market Performance', OECD Employment Outlook, Organisation of Economic Cooperation and Development, Paris.

Palley, T.I. (1998) 'Restoring Prosperity: Why the U.S. Model is not the Answer for the United States or Europe', Journal of Post Keynesian Economics, 20(3), 337-53, Spring.

Palley, T.I. (2004) 'From Keynesianism to Neoliberalism: Shifting Paradigms in Economics', in Johnston, D. and Saad-Filho, A. (eds.) Neoliberalism - A Critical Reader, Pluto Press, London. 
Polanyi, K. (1957) The Great Transformation: The Political and Economic Origins of our Time, Beacon Press, Boston.

Richardson, S. and Harding, A. (1999) 'Poor Workers? The Link between Low Wages, Low Family Income and the Tax and Transfer Systems' in Richardson, S. (ed.) Reshaping the Labour Market: Regulation, Efficiency and Equality in Australia, Cambridge University Press, Melbourne, 122-158.

Thurow, L. (1983) Dangerous Currents: The State of Economics, OUP, Oxford.

Watson, I. (2004) 'A Needle in a Haystack: Do Increases in the Minimum Wage Cause Employment Losses?', ACIRRT Working Paper, 90, March

World Bank (2003) Unions and Collective Bargaining: Economic Effects in a Global Environment, Washington, February. 
Copyright of Australian Journal of Social Issues is the property of Australian Council of Social Service and its content may not be copied or emailed to multiple sites or posted to a listserv without the copyright holder's express written permission. However, users may print, download, or email articles for individual use. 